\title{
Financial adaptation to disaster risk in the European Union
}

\section{Identifying roles for the public sector}

\author{
Stine Aakre • Ilona Banaszak • Reinhard Mechler • \\ Dirk Rübbelke • Anita Wreford • Harvir Kalirai
}

Received: 13 August 2009 /Accepted: 3 May 2010 /

Published online: 10 June 2010

C The Author(s) 2010. This article is published with open access at Springerlink.com

\begin{abstract}
Increasing losses from weather related extreme events coupled with limited coping capacity suggest a need for strong adaptation commitments, of which public sector responses to adjustments to actual and expected climate stimuli are key. The European Commission has started to address this need in the emerging European Union (EU) climate adaptation strategy; yet, a specific rationale for adaptation interventions has not clearly been identified, and the economic case for adaptation to extremes remains vague. Basing the diagnosis on economic welfare theory and an empirical analysis of the current EU and member states' roles in managing disaster risk, we discuss how and where the public sector may intervene for managing climate variability and change. We restrict our analysis to financial disaster management, a domain of adaptation intervention, which is of key concern for the EU adaptation strategy. We analyse three areas of public sector interventions, supporting national insurance systems, providing compensation to the affected post event as well as intergovernmental loss sharing through the EU solidarity fund, according to the three government functions of allocation, distribution, and stabilization suggested by welfare theory, and suggest room for improvement.
\end{abstract}

S. Aakre • D. Rübbelke

Center for International Climate and Environmental Research, Oslo (CICERO), Oslo, Norway

I. Banaszak

Polish Academy of Sciences, Poznań, Poland

I. Banaszak

Slovak Academy of Sciences, Bratislava, Slovakia

R. Mechler $(\bowtie) \cdot$ H. Kalirai

International Institute for Applied Systems Analysis (IIASA), Laxenburg, Austria e-mail: mechler@iiasa.ac.at

D. Rübbelke

Basque Centre for Climate Change (BC3), Gran Via, 35-2, 48009, Bilbao, Spain

D. Rübbelke

IKERBASQUE: Basque Foundation for Science, 48011, Bilbao, Spain

A. Wreford

Scottish Agricultural College (SAC), Edinburgh, UK

A. Wreford

Tyndall Centre for Climate Change Research, University of East Anglia, Norwich, UK 
Keywords Welfare economics · Adaptation · Disaster risk management · Risk financing · Insurance

\section{Introduction: a need for managing climate variability and change}

Escalating increases in disaster losses from floods, droughts, and other climate-related disasters both in developed and developing countries have become a major concern over the last years. There is mounting evidence of a significant climate-change signal in natural disaster events, for example, increasing extreme precipitation at mid- and high-latitudes (Schönwiese et al. 2003), extreme floods and droughts in temperate and tropical Asia, severe dry events in the Sahel and southern Africa (Solomon et al. 2007), and increases in tropical cyclone activity in the Atlantic and the Pacific region (Emanuel 2005). Projections suggest that those changes are expected to continue to contribute to natural hazards in many places in the future (Solomon et al. 2007). Also, in Europe, there is evidence of rising losses of extreme weather events and many regions and sectors in Europe are vulnerable to natural hazards. The number of disastrous weather and climate-related events in Europe per year doubled over the 1990s compared with the previous decade, while non-climatic events such as earthquakes remained constant. Until 2004, four of the 5 years with the largest economic losses have occurred since 1997 (EEA 2004). Among others, the 2002 large-scale flooding over central Europe and the 2003 heat wave of unprecedented magnitude resulting in 70,000 deaths, placed risk management and adaptation at the top of the agenda (EC 2007a).

Losses and risks are not well managed and shared out under the current climate regime, and in order to minimise future losses and impacts as projected to be exacerbated by climate change, it is important to improve upon the management of current (disaster risk management) and future climate variability (climate adaptation). Yet, while mitigation has received wide coverage in the scientific literature, there is need for better exploring the characteristics of and adequate approaches to adaptation policy, one important aspect relating to defining appropriate roles for the public sector and public policy.

Lately, the European Union (EU) Commission Green and White Papers on Adaptation to Climate Change (EC 2007a, 2009) have started to address this need and for the first time marked the onset of a consolidated EU climate adaptation strategy. The papers argue in favour of a multi-level approach to the governance of adaptation, with specific member states and EU roles at different governance levels. Managing disaster risk is considered a priority area for action on adaptation and features prominently in the strategy reports, which call for early policy response in order to prevent significant future costs associated with reactive unplanned adaptation. The strategy laid out holds that where current knowledge is sufficient, adaptation strategies should be developed in order to identify optimal resource allocation and efficient resource use for guiding EU action through sectoral and other policies. In turn, for significant knowledge gaps, research, exchange of information, and preparatory action should be enhanced to further contribute to expanding the knowledge base and managing uncertainty. ${ }^{1}$ Yet, overall, no specific rationale for adaptation intervention is given in these official documents, and the economic case for adaptation remains vague with the papers stating that autonomous adaptation responses of individuals

\footnotetext{
${ }^{1}$ Along the classical distinction by Knight (1921), in this paper we distinguish between risk as "measurable uncertainty," such as represented by probability distributions of disaster losses, and "unmeasurable" uncertainty.
} 
and businesses to price signals or climate change stimuli are unlikely to be optimal given the large associated uncertainties, imperfect information and financial constraints.

A few studies have examined this case more thoroughly. Klein and Tol (1997) argue that public policy related to adaptation should have four objectives: increasing robustness of infrastructures; increasing flexibility and adaptability of vulnerable managed systems; reversing trends that increase vulnerability; and improving awareness and preparedness. Berkhout (2005) points out that, prima facie, it is not evident that governments should actually play a role in influencing adaptation to climate change, compared to the clear-cut case for mitigative action to protect public goods like the climate system. He further proposes seven objectives for public adaptation policy (some of which overlap with Klein and Tol's): to inform the potentially vulnerable; to assist in the provision of disaster relief; to provide incentives for and enable adaptation; to mainstream climate-proofing of public policy; to plan and regulate long-term infrastructural assets to reduce future vulnerabilities; to regulate adaptation 'spillovers'; and to compensate for the unequal distribution of climate impacts.

Our analysis adds to this more empirically based discussion on appropriate governmental adaptation responses by taking recourse to normative economic welfare theory, a branch of economics which assesses society's welfare based on the objectives of allocative efficiency, distribution among agents and stabilization of the economy (Musgrave 1959). Over the last 50 years, welfare theory has been widely used to assess government policies, and considered one rigorous way of framing questions of government intervention. Using this approach and based on an analysis of current EU and member states roles in adaptation, we examine whether and where adaptation in the EU should be influenced by governments and how governments should intervene in order to help facilitate adaptation.

There are different dimensions of disaster risk management and climate adaptation, which include autonomous, planned, private and public adaptation measures. ${ }^{2}$ We restrict our analysis to financial disaster risk management, a domain of adaptation intervention, where these four types of intervention are interacting, and which is a key concern for adaptation as stated in the Green and White Papers of the EU. Our analysis mostly focuses on planned, public sector adaptation to extreme events and the public sector's facilitating role in helping the private sector better adapt. Examining insurance and compensation systems as key risk management mechanisms in the EU, we find that market forces are unlikely to generate adequate adaptation responses to climate risk due to uncertainty and imperfect information, missing and misaligned markets and financial constraints. This calls for government intervention, which we analyze according to its allocation, distribution, and stabilization functions.

We proceed as follows. In Section 2 we define the functions and obligations of public policy suggested by welfare theory: allocation, distribution and stabilization (see Musgrave 1959), before specifically identifying risks incurred by governments and other public sector institutions as well as options for managing those. In Section 3 we analyse current approaches to financially managing disaster risk for the EU and its member states. We distinguish between governmental interventions to support strategies pursued by individual households and businesses, and those taken to help governments and public sector institutions to financially adapt. In Section 4 we suggest improvements to the assignment of the EU's and member states' roles in disaster adaptation policy, and discuss these in light of the three welfare theoretic functions, before Section 5 concludes.

\footnotetext{
${ }^{2}$ Smit et al. (1999, 2000) provide a systematic specification and differentiation of adaptations, which is based on three questions: 1) "adapt to what?", 2) "who or what adapts?", 3) "how does adaptation occur?".
} 


\section{Identifying the roles for the public sector in adaptation}

From an economic perspective, three main functions for governments and the public sector can be identified: (i) generating an efficient allocation of goods and services (e.g. security, education, clean and stable environment), (ii) ensuring an adequate distribution of income, as well as (iii) stabilizing the economy (Musgrave 1959). The justification for government intervention in the economy can be derived from the two fundamental theorems of welfare economics. The first theorem postulates that under certain conditions a competitive market economy without government intervention results in a Pareto-efficient outcome; the second that an equitable Pareto-efficient market outcome can be reached by a redistribution of initial endowments. The rationale for government intervention thus comes from a violation of these two theorems due to the existence of externalities and imperfect information. Externalities are costs or benefits caused by one economic agent and bearing on another that did not agree on an action or transaction causing the externalities. Externalities and public goods characterized by non-rivalry and non-excludability are closely related. Nonrivalry refers to the fact that consumption of the good by one agent does not reduce availability of the good for consumption by others, while non-excludability refers to the fact that it is not possible to prevent agents who have not paid for providing the good from having access to it. When a good is characterized by non-excludability in consumption, free-rider incentives arise concerning their provision. Since public goods are typically not (efficiently) provided by the market, government intervention is required to ensure adequate provision. Violations of the second theorem occur due to the inability to redistribute initial endowments without governmental intervention (Devarajan and Hammer 1997). The desire to attain a specific (e.g. more equitable) distribution calls for redistribution, which is accomplished, for example, by means of progressive taxation and transfer payments.

\subsection{The case for government intervention in adaptation to extremes}

Taking a welfare economics perspective to adaptation to extremes, it can be argued that this leads to three different sources of risk that governments become involved in through serving the abovementioned functions (Mechler 2004; Aakre and Rübbelke 2010). First, governments are exposed to risk due to their complete provision of public goods and services, such as coastline defence. As to the first source of risk, in many instances, it is the public sector that is highly exposed to today's and future disaster risks. Often, time horizons for relevant planning decisions to protect the exposed sectors are large suggesting future changes need to be accounted for in today's decisions (Table 1). In the case of partial market failure, governments often assume the risk to which the private sector is exposed or share it out with private agents, such as is often the case for building water infrastructure or when being the final risk bearer. Natural disaster insurance is another example and governments are actually often called "insurers of last resort" and "the most effective insurance instrument of society" (Priest 1996) in the sense that they are often the final entity that private households and firms can turn to post-event in case of need for compensation, or pre-event acquire government-provided insurance from.

Second, governments are exposed to risk through their redistributional role. Governments redistribute income to those members of society that are in need of help before or after disaster events. After disasters, the poor, as well as those in danger of slipping into poverty, need government relief payments to be able to sustain a basic standard of living. This is particularly the case for countries with low per capita income and/or large proportions of the population in poverty. Before actual disaster events, uncertainty, budget constraints, 
Table 1 Exposure of the public and private sectors to disaster risk

\begin{tabular}{|c|c|c|c|}
\hline Sector decisions & Exposed agents & $\begin{array}{l}\text { Time scale } \\
\text { (year) }\end{array}$ & $\begin{array}{l}\text { Degree of } \\
\text { exposure }\end{array}$ \\
\hline Land-use planning (e.g., in flood plain or coastal areas) & Public & $>100$ & +++ \\
\hline Coastline and flood defences (e.g., dikes, sea walls) & Public & $>50$ & +++ \\
\hline Urbanism (e.g., urban density, parks) & Mostly public & $>100$ & + \\
\hline Water infrastructure (e.g., dams, reservoirs) & Public and private & $30-200$ & +++ \\
\hline Building and housing (e.g., flood proofing) & Public and private & $30-150$ & ++ \\
\hline $\begin{array}{l}\text { Transportation infrastructure (e.g., port, bridges affected } \\
\text { by flooding) }\end{array}$ & Public and private & $30-200$ & + \\
\hline $\begin{array}{l}\text { Energy production (e.g., nuclear plant cooling systems } \\
\text { affected by droughts) }\end{array}$ & Public and private & $20-70$ & + \\
\hline
\end{tabular}

Source: Hallegatte 2009

inertia and cultural factors prevent people from making optimal adaptation decisions (Stern 2007), as well implying a need for government support and intervention. Uncertainty about future climate change is an important factor in accounting for the low level of preparedness in response to extreme events in the EU, for two reasons. Where households perceive early rewards or benefits from their actions, they are likely to take action. However, when there is uncertainty regarding the benefits of adaptation and the costs are apparent and high, households are unlikely to act (Mendelsohn 2000). Also, uncertainty can lead to insurance premiums being set at either too high or too low a level, both of which sends the wrong signal to households and may result in under-insurance (if premiums are too high) or unsustainable losses to the insurance sector if the premiums are low and a disaster does occur. Where private action fails because of a lack of appropriate incentives to act, insufficient property rights and social barriers to adapt, governments may thus have to provide adaptation as a public good. This may include publicly funded adaptation measures to bring risks down to an acceptable (and hence affordable) level, as well as possibly facilitating the sharing of climate risks between the insurance sector and the state. As well, providing information about the likely changes and impacts, and options for adaptation may facilitate better household risk management. The scale and/or efficiency of many adaptations undertaken by governments may be enhanced through engagement with the private sector (Agrawala et al. 2008).

Third, given large demand and supply side shocks, there is a need to stabilize the economy. Stabilization policy aims at improving the performance characteristics of the economy by guiding it onto a promising development path and adopting favourable structural changes and policy responses. Stabilization policy actions need not only consider immediate effects but also look at longer-term policy impacts (Culbertson 1974).

\section{Current approaches to financially managing disasters in the EU and its member states}

\subsection{Disaster management}

Disaster management covers a wide array of interventions as shown in Table 2 comprising of ex ante interventions (prevention, preparedness and risk financing) as well as ex post action (relief and reconstruction). The balance today is still tilted heavily to ex post 
Table 2 The scope of disaster management

\begin{tabular}{|c|c|c|c|c|}
\hline \multirow{2}{*}{$\begin{array}{l}\text { Timing } \\
\text { Type }\end{array}$} & \multicolumn{3}{|l|}{ Ex ante } & \multirow{2}{*}{$\begin{array}{l}\text { Ex post } \\
\text { Managing the impacts }\end{array}$} \\
\hline & Prevention & Preparedness & Risk financing & \\
\hline Effect & Reduces risk & Reduces risk & $\begin{array}{l}\text { Transfers risk (reduces } \\
\text { variability) }\end{array}$ & $\begin{array}{l}\text { Reducing the impacts } \\
\text { (relief) and rebuilding } \\
\text { the losses } \\
\text { (reconstruction) }\end{array}$ \\
\hline \multirow[t]{3}{*}{$\begin{array}{l}\text { Key } \\
\text { options }\end{array}$} & $\begin{array}{l}\text { Physical and } \\
\text { structural mitigation } \\
\text { works (e.g. irrigation, } \\
\text { embankments) }\end{array}$ & $\begin{array}{l}\text { Early warning } \\
\text { systems, } \\
\text { communication } \\
\text { systems }\end{array}$ & $\begin{array}{l}\text { Risk transfer (by means } \\
\text { of (re-) insurance) for } \\
\text { public infra-structure } \\
\text { and private assets, } \\
\text { microinsurance }\end{array}$ & $\begin{array}{l}\text { Providing relief to } \\
\text { the affected and } \\
\text { compensating losses }\end{array}$ \\
\hline & $\begin{array}{l}\text { Land-use planning } \\
\text { and building codes }\end{array}$ & $\begin{array}{l}\text { Contingency planning, } \\
\text { networks for } \\
\text { emergency response }\end{array}$ & Alternative risk transfer & Supporting recovery \\
\hline & $\begin{array}{l}\text { Economic incentives } \\
\text { for proactive risk } \\
\text { management }\end{array}$ & $\begin{array}{l}\text { Shelter facilities, } \\
\text { evacuation plans }\end{array}$ & $\begin{array}{l}\text { National and local } \\
\text { reserve funds }\end{array}$ & $\begin{array}{l}\text { Rebuilding housing } \\
\text { and infrastructure }\end{array}$ \\
\hline
\end{tabular}

Source: Based on IDB 2000

interventions with about $95 \%$ of total funds available for disaster management being spent here (see Mechler 2004).

Financial support after events can be provided by arranging ex-post relief after the fact or implementing insurance systems before a disaster event materializes. In this paper, we focus on both these options and do not further dwell on other adaptation action in individual member states or the EU, such as flood defences or early warning systems, although these actions play an important, and often key, role in managing disaster risk and reducing vulnerability to disasters.

There are many modalities for exposed agents, households, farms and businesses and governments, to use risk financing instruments. The best known instrument is insurance providing indemnification against losses after an event in exchange for a premium payment before events (Kunreuther 1998). What is less well known is that governments may also use this option (sovereign insurance). Yet, there is a whole array of pre- and post-disaster arrangements for financing recovery, such as savings, kinship arrangements or raising tax revenue or building mutual pools (Table 3 ).

Two main approaches exist for absorbing climate change related risks; via ex ante insurance and via ex post compensation. Globally, the insurance industry is a minority payer for catastrophe losses: In 2001 about $32 \%$ of total natural disaster losses were insured (Munich Re 2002). ${ }^{3}$ The larger part of the losses had to be borne by the affected parties, federal, state or local governments, and, in highly affected countries with little coping, the international donor community. Figure 1 shows a cross-country sample of the financing of major disasters in Europe. In addition to insurance markets, governments as 'insurers of last resort' have had an important role in supporting infrastructure reconstruction and relief support for households and businesses. Government spending as a share of direct losses ranged from $11 \%$ (drought in Portugal) to $48 \%$ (flooding in Poland). The only outlier in

\footnotetext{
$\overline{3}$ These figures only include large natural disasters.
} 
Table 3 Types of pre- and post-disaster risk financing arrangements

\begin{tabular}{|c|c|c|c|}
\hline Timing & $\begin{array}{l}\text { Type of } \\
\text { intervention }\end{array}$ & $\begin{array}{l}\text { Farms/households/businesses: } \\
\text { loss of assets and crops }\end{array}$ & $\begin{array}{l}\text { Governments: relief and } \\
\text { reconstruction expenditure }\end{array}$ \\
\hline $\begin{array}{l}\text { Loss sharing } \\
\text { (ex post) }\end{array}$ & $\begin{array}{l}\text { Market and } \\
\text { non-market }\end{array}$ & $\begin{array}{l}\text { Savings, sale of productive assets, } \\
\text { emergency loans, money lenders; } \\
\text { public assistance }\end{array}$ & $\begin{array}{l}\text { Taxes, diversions, loans from } \\
\text { international financial institutions }\end{array}$ \\
\hline \multirow[t]{3}{*}{$\begin{array}{l}\text { Risk financing } \\
\text { (ex ante) }\end{array}$} & Non-market & $\begin{array}{l}\text { Kinship and voluntary mutual } \\
\text { arrangements }\end{array}$ & International aid \\
\hline & Inter-temporal & Micro-savings, food storage & $\begin{array}{l}\text { Catastrophe reserve funds, regional } \\
\text { pools, contingent credit }\end{array}$ \\
\hline & $\begin{array}{l}\text { Market-based } \\
\text { risk transfer }\end{array}$ & $\begin{array}{l}\text { Property, life, crop and livestock } \\
\text { insurance (also index based) }\end{array}$ & $\begin{array}{l}\text { Insurance or catastrophe bonds } \\
\text { (also index based) }\end{array}$ \\
\hline
\end{tabular}

Source: Linnerooth-Bayer and Mechler 2007

Europe has historically been the UK, with a large insurance penetration and almost no relief provided to the affected, which can be attributed to an (unwritten) compact holding that the government is responsible for structural risk management while households and business need to take action in terms of insurance (Mechler et al. 2010). ${ }^{4}$

In the rest of this section, we now explore current practices across EU member states with regard to insurance and compensation, limiting our attention to flood and drought risks.

\subsection{Ex ante risk financing: disaster insurance for households, farmers and business}

Insurance for natural disasters is usually offered as a voluntary extension of property insurance and household contents insurance. We focus on flood and drought risks, which are most prevalent in the EU. For both flood and drought insurance there is a wide variety of systems available. Insurance as a key instrument for coping with extreme event risk has been discussed widely in the risk management and adaptation literature (see, Van den Bergh and Faure 2006; Bouwer et al. 2007; Botzen and van den Bergh 2008; Dlugolecki 2008; Treby et al. 2006). In general, insurance serves to reduce the overall risk levels to society through three main functions: i) the aggregation of risks; ii) the segregation of risks into separate pools; and iii) the control of moral hazard (Priest 1996).

\subsubsection{Flood insurance}

The availability of private flood insurance is quite widespread in the EU, yet actual cover is often limited. Two main categories of private flood insurance can be distinguished: the "option system" and the "bundle system" (Crichton 2002, 2008). In the former, insurance policies are extended to include flood for an additional premium. By contrast, in the latter system, flood cover is only available as a package with other perils (e.g. fire, storm, earthquake). Since flood risks are not necessarily uniformly distributed, one potential problem with the optional cover is adverse selection, which may ultimately result in expensive cover and low market penetration (Crichton 2008). The bundled approach, which is a widely used tool to achieve risk aggregation, entails less risk of adverse selection and is generally characterized by much higher market penetration (Crichton 2008; OECD 2005).

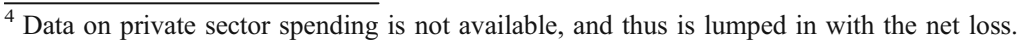


$\square$ Private sector and net loss

년 Government

$\square$ Insurance

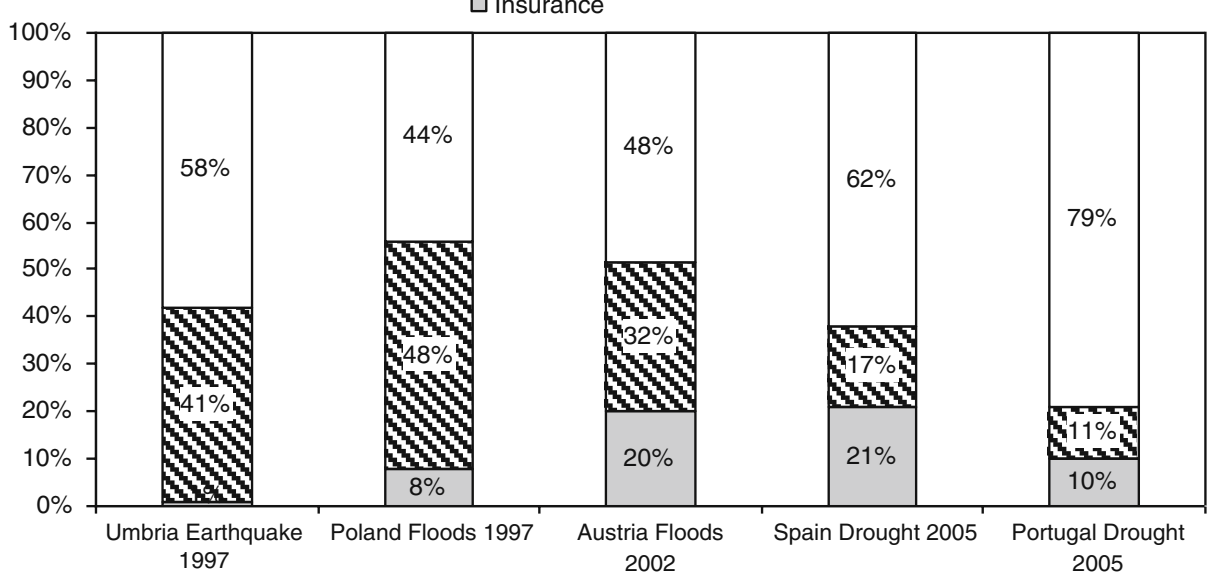

Fig. 1 Cross-country sample of financing modalities of disaster losses by insurance, government assistance, and private sector in Europe (as a percentage of direct losses). Source: Mechler et al. 2010

However, if the program is mandatory (as bundled options often are) there is a high level of moral hazard (OECD 2005; Swiss Re 1998). Currently, insurance penetration rates range from very low in some countries (e.g. the Netherlands) to close to full insurance in others (e.g. the United Kingdom). Differences in demand for private coverage might be explained by differences in risk exposure, expectation of state intervention, underestimation of risk and/or difficulties in meeting the conditions of insurability (CEA 2009).

Table 4 summarizes the key properties of insurance and compensation systems for covering losses incurred by households and business in a selection of EU member states. We distinguish between private insurance systems and government solutions. In the former, member state approaches are further categorized according to whether they belong to the so-called "bundle system" or the "option system". With regard to government approaches, we consider systems based on ex post compensation by the government (where flood loss compensation is paid from tax revenues). The fifth column indicates whether private insurance is compulsory. Finally, we estimate the level of market penetration of the insurance system.

\subsubsection{Agricultural insurance for drought risks}

Agriculture insurance coverage varies across the EU. The variation comes from the types of risks that are insured, how they are bundled (e.g., single-risk insurance, combined insurance, yield insurance) and how they are shared between the private and public sectors. In some cases the public sector heavily subsidises insurance premiums and in other cases ad-hoc aid and calamities funds represent the government's choice of intervention. In Spain, Austria, Portugal, Greece, and Sweden there are no public payments if insurance is available. The Mediterranean countries France, Greece, Italy, Portugal and Spain are most at risk from droughts, and Table 5 summarizes systems in these countries. Spain, as a case in point, has one of the most advanced and elaborate agriculture insurance systems in the EU. Crop insurance has developed significantly in Spain over the last 30 years to the 
Table 4 Insurance and compensation systems in the European Union

\begin{tabular}{|c|c|c|c|c|c|}
\hline \multirow[t]{2}{*}{ Member state } & \multicolumn{3}{|c|}{ Insurance/compensation system } & \multirow{2}{*}{$\begin{array}{l}\text { Insurance } \\
\text { compulsory }\end{array}$} & \multirow{2}{*}{$\begin{array}{l}\text { Market } \\
\text { penetration }\end{array}$} \\
\hline & $\begin{array}{l}\text { Private, ex ante } \\
\text { premium bundled }\end{array}$ & $\begin{array}{l}\text { Private, ex ante } \\
\text { premium optional }\end{array}$ & $\begin{array}{l}\text { Government, ex post } \\
\text { compensation }\end{array}$ & & \\
\hline Austria & & $\mathrm{X}$ & & & $10-25 \%$ \\
\hline Belgium & $\mathrm{X}$ & & & $\mathrm{X}$ & $>75 \%$ \\
\hline Czech Rep. & & $\mathrm{X}$ & & & $25-75 \%$ \\
\hline Finland & & $\mathrm{X}$ & $\mathrm{X}$ & & $10-25 \%$ \\
\hline France & $\mathrm{X}$ & & & $\mathrm{X}$ & $>75 \%$ \\
\hline Germany & & $\mathrm{X}$ & $\mathrm{X}$ & & $10-25 \%$ \\
\hline Greece & $\mathrm{X}$ & & $\mathrm{X}$ & & $<10 \%$ \\
\hline Hungary & $\mathrm{X}$ & & $\mathrm{X}$ & & $40 \%-60 \%$ \\
\hline Italy & & $\mathrm{X}$ & & & $<10 \%$ \\
\hline Netherlands & & $\mathrm{X}$ & $\mathrm{X}$ & & $<5 \%$ \\
\hline Poland & & $\mathrm{X}$ & $\mathrm{X}$ & & $25-75 \%$ \\
\hline Portugal & $\mathrm{X}$ & & & & $25-75 \%$ \\
\hline Spain & $\mathrm{X}$ & & $\mathrm{X}$ & $\mathrm{X}$ & $25-75 \%$ \\
\hline Sweden & $\mathrm{X}$ & & $\mathrm{X}$ & & $>75 \%$ \\
\hline UK & $\mathrm{X}$ & & & & $>75 \%$ \\
\hline
\end{tabular}

Sources: Bouwer et al. (2007); CEA (2009); Swiss Re (1998); ISDR (2005); OECD (2005); Paklina (2003)

current private-public agriculture insurance system which is greatly subsidized by the government. The Spanish point of view is that the cost of subsidizing insurance premiums is less costly than emergency relief payments following a disaster. In the event that public funds are provided for drought relief, farmers who opted to not buy crop insurance when it was available are not eligible for government funds to provide relief. Insurance coverage is close to $45 \%$ for all the agricultural production (and above $70 \%$ for winter cereals and fruits). In France, there is very low government subsidization of insurance premiums $(2.4 \%)$ compared to the other Mediterranean countries. However, the French government provides significantly greater ad-hoc aid, $€ 156$ million per year on average over the 1996-2005 period compared to less than the $€ 5$ million average per year for both Spain and Portugal.

Table 5 Comparison of agriculture insurance systems for EU Mediterranean countries

\begin{tabular}{llllllll}
\hline & $\begin{array}{l}\text { Single-risk } \\
\text { insurance }\end{array}$ & $\begin{array}{l}\text { Combined } \\
\text { insurance }\end{array}$ & $\begin{array}{l}\text { Yield } \\
\text { insurance }\end{array}$ & $\begin{array}{l}\text { Calamities } \\
\text { fund }\end{array}$ & Ad-hoc aid & $\begin{array}{l}\text { Premium/ insured } \\
\text { value (\%) }\end{array}$ & $\begin{array}{l}\text { Insurance } \\
\text { subsidies (\%) }\end{array}$ \\
\hline France & P & P & PS & GS & GF & $1.7 \%$ & $2.4 \%$ \\
Greece & G & GC+GS+G & - & - & GF & $2.5 \%$ & no data \\
Italy & PS & PS & PS & GF & GF & $7.4 \%$ & $67.0 \%$ \\
Portugal & PS & PS & - & GS & GF & $8.4 \%$ & $68.0 \%$ \\
Spain & PS & PS & PS & - & GF & $6.3 \%$ & $41.0 \%$ \\
\hline
\end{tabular}

Source: EC 2006

P private, non-subsidised; PS private, partially subsidised; G public, non-subsidised; GS public, partially subsidised; GF public, free 


\subsection{Private sector loss sharing via government compensation}

The extent of government intervention in the form of compensation varies across member states. Where it exists, compensation may be offered either ad hoc or in institutionalised form (Bouwer et al. 2007; Crichton 2008; Paklina 2003). Recent examples of ad hoc relief can be found in Germany, while the Dutch system represents an example of the latter approach. The extent to which compensation is available varies across EU member states. For instance, while no government compensation exists in the UK, the Netherlands has offered compensation of catastrophic losses since 1998 through the Calamities Compensation Act. In Sweden, there is currently no national catastrophe fund aimed at compensating losses incurred by floods. However, financial assistance may be offered in the case of major disasters, on an ad hoc basis (Van den Bergh and Faure 2006).

It is worth noting that compensation in case of extreme events is not an adaptation measure per se, since no climate change damage is prevented. This contrasts with insurance, which does not reduce the losses, yet reduces the follow-on economic impacts and thus stabilizes the income and consumption stream of the affected, and thus clearly reduces vulnerability and impacts (see Linnerooth-Bayer and Mechler 2007).

Further, compensation is relevant for adaptation in the sense that it may adversely influence the incentives to produce adaptation measures. For instance, the existence of public compensation schemes can adversely affect incentives to buy private insurance. However, as Aakre and Rübbelke (2010) discuss, while the existence of public compensation schemes may crowd out private market insurance solutions, hence threatening allocative efficiency, equity considerations may nevertheless justify compensation paid from tax revenues. A study conducted by Whyley et al. (1998) on the UK insurance market, suggests that almost half of those without flood insurance are unable to access insurance due to financial constraints.

\subsection{Public sector relief expenditure loss sharing: the EU solidarity fund}

Many risks end up with central governments and may lead to large financial and economic implications. As also discussed in the paper by Mechler et al. in this issue, such explicit (government infrastructure reconstruction funding after events) or implicit disaster government liabilities (bailing out the affected population post event) can have large scale repercussions on a government position. The case of the aftermath of the large scale flooding in Austria, which led to the downfall of the government coalition is one example. Overall, in Europe, there are a number of emerging economy countries (basically the new Eastern European Member Countries), which after joining the EU, are in need to adapt their economies to the more rigorous and changed fiscal and economic conditions' and at the same time are exposed to large implicit and explicit disaster liabilities. If such liabilities are not well recognized and interact with other stresses such as the ongoing financial crisis, then, in case of disaster events, they may well help to destabilize a government's fiscal stance and the economy.

Recognising that floods and other disasters may lead to overburdening national governments and necessitate international assistance even in Europe, the EU Solidarity Fund (EUSF) was created after the floods in central Europe in summer 2002 and entered into force already on November 15 th of that year (EUFR 2004). ${ }^{5}$ Member states, and countries applying for accession, can request aid in the event of a major natural or

\footnotetext{
${ }^{5}$ More detail on the solidarity fund and its viability, legitimacy and efficiency can be found in the paper by Hochrainer, Linnerooth-Bayer and Mechler in this issue.
} 
technological disaster (EUFR 2002). The fund provides financial aid for emergency measures in the event of a natural disaster causing direct damages above 3 billion Euros (at 2002 prices) or $0.6 \%$ of the GNI (Council Regulation 2002). Fund support can be mobilized even if the threshold is not met, e.g. for a neighbouring country that is affected by the same major natural disaster or for extraordinary regional disasters which affect the majority of the population of a region and have serious effects on its economic stability and living conditions. The payments from the Fund are limited to finance operations undertaken by the public authorities alleviating non insurable damages (e.g. restoring infrastructure operation) (Council Regulation 2002). The European Commission decides the amount of aid and proposes its mobilization. The maximum annual budget is 1 billion Euros per year (EUFR 2004). The amount annually available for extraordinary regional disasters is limited to $7.5 \%$ of the EUSF's annual budget (Council Regulation 2002). However, the actual amount varies from year to year, depending on the occurrence of disasters.

Since its creation, almost all EU countries have asked for support from the fund, and many in fact have received assistance. There have even been situations, such as in 2002 and 2003 after large scale flooding in central Europe, where the fund was nearly depleted already in the middle of the year. In relative terms, the support granted through the EUSF is still small compared to the damages incurred; for example, Austria received 134 million Euro for financing flood losses in 2002 compared to a total direct damage of 2,900 million Euro. Member states have suggested that the criterion of the EUR 3 billion losses to acquire access to the EUSF is set too high, and that he criterion of at least half of an affected region's population having incurred losses may also not easily be fulfilled. Further, while specific EU funds to address floods exist, there is no equivalent to addressing drought and water scarcity. In this domain, problems may become more pronounced if losses are increasing and the scope for applying for relief payments is widened, as is currently discussed in the EU. The Commission has actually already expressed its readiness to examine all requests for EUSF aid following droughts but will ensure that "the request is not the indirect result of inefficient water management and that appropriate drought management plans are in place" (EC 2007b). Moreover, the Commission will assess whether changes need to be made to the definition of the criteria and eligible operations so that the EUSF may respond better to drought and other events, which are currently not covered.

\section{Improving government interventions}

It emerges that public sector interventions in the financial management of disasters in the EU and elsewhere are rather mixed and can have positive as well as negative impacts on allocation, distribution and stabilization. As we observe from the examples of insurance, disaster relief and compensation, there are synergies and trade-offs between the three functions of government intervention suggested by welfare economics.

Insurance in theory should well serve to allocate risks efficiently. In a perfect market, risk-based insurance products send signals to the market and to households regarding the proper economic cost of managing risk. Households accordingly respond to price signals by making changes rendering properties more resilient to extreme events and climate change (in turn leading to reduced insurance premiums), increasing the degree of insurance, or even relocating to less risky areas. According to Bouwer et al. (2007), increasing flood insurance penetration may contribute to higher adaptability to changes in exposure to, and probabilities of flooding. More specifically, as Crichton (2008) comments, flood insurance as an economic instrument can play an important role in providing "direct economic 
incentives to individuals to relocate or take their own precautions against flood while at the same time facilitating rapid economic recovery after a flood."

In reality, as discussed above, insurance markets are rather imperfect, and government support is necessary and widespread in the EU and elsewhere. Governments of EU member states regulate, subsidize or even offer insurance for flood or drought risks; yet, in many instances markets and public-private partnership offer only limited coverage or are extremely restricted, such as for flood risk in the Netherlands, which leads to substantial government liabilities for member states, which to some extent are buffered by the EU solidarity fund government compensation scheme.

What may be done to improve on existing solutions and what are effects on allocation, distribution as well as stabilization? In terms of insurance systems, governments may better identify the case for subsidies or impose mandatory insurance solutions; provide improved risk information and technical assistance for alternative risk transfer schemes (Table 6).

Providing subsidies or imposing mandatory insurance (such as done in France and Spain) would lead to a much wider coverage of the insured. As insurance is based on the law of large numbers, a larger pool due to the risk diversification effect should lead to lower premiums for all and thus better help allocate risk. On the other hand, premium subsidies can lead to distorting the price signal and thus weaken incentives for taking preventive measures; thus they may lead to locking people into risky states by making it possible to remain in high-risk occupations or locations (Skees 2001). The issue of incentives seems important, yet the degree of the effect remains debatable given the fact that disaster insurance markets are distorted in the first place as discussed above. On the other hand, as with compensation, the issue of moral hazard merits attention, i.e. the fact that being covered explicitly (by insurance) or implicitly (by government compensation) leads agents to relax their efforts to reduce risk.

As well, supporting the development of new instruments holds promise. Particularly for weather risks, novel risk management options are being explored that can augment traditional insurance. Examples worth exploring include alternative risk transfer mechanisms such as financial derivatives such as options and futures to hedge against crop losses and catastrophe bonds (which may be difficult in the case of droughts since the hazard is slow onset). To avoid

Table 6 Current and suggested adaptation interventions of EU and member states in terms of financially managing disaster events

\begin{tabular}{|c|c|c|c|c|c|}
\hline $\begin{array}{l}\text { Flood and drought } \\
\text { insurance system } \\
\text { for households, } \\
\text { farmers and } \\
\text { business }\end{array}$ & $\begin{array}{l}\text { Regulated, subsidized } \\
\text { or offered by member } \\
\text { states; in many } \\
\text { instances markets } \\
\text { offer only limited } \\
\text { coverage or do not } \\
\text { exist at all }\end{array}$ & $\begin{array}{l}\text { Identify cases for insurance } \\
\text { premium subsidies or } \\
\text { mandatory insurance; } \\
\text { provide improved risk } \\
\text { information and technical } \\
\text { assistance for alternative } \\
\text { risk transfer schemes }\end{array}$ & $+/-$ & + & 0 \\
\hline $\begin{array}{l}\text { EU compensation } \\
\text { fund for } \\
\text { governments }\end{array}$ & $\begin{array}{l}\text { Ex post solidarity fund } \\
\text { providing support for } \\
\text { larger scale events }\end{array}$ & $\begin{array}{l}\text { Remodel to risk-based } \\
\text { solidarity fund }\end{array}$ & + & + & + \\
\hline
\end{tabular}


the high transaction costs of indemnity-based insurance systems, index-based or parametric schemes make payouts contingent on a physical trigger, such as rainfall measured at a regional weather station, circumventing expensive claims settling. In the case of weather derivatives, farmers collect an insurance payment if the index reaches a certain measure or "trigger" regardless of actual losses. These schemes may offer a less costly and thus more viable alternative to traditional indemnity-based crop insurance (see Linnerooth-Bayer and Mechler 2007). Another issue is availability, exchange and communication of data such as flood risk maps. Oftentimes, these data are not shared between research institutes, private companies (e.g. insurers), state agencies, local governments and endusers. Communication of location-specific information seems key, as empirical evidence shows that adaptation outcomes are influenced by location-specific factors such as the type and severity of a hazard or extreme event at a given place, the vulnerability and exposure of different elements at risk, but also perception of potential risk by decision-makers, political and institutional context, cultural heritage, and availability of resources (McEvoy et al. this issue).

In terms of compensating victims after the event, where governments offer compensation ex post either ad hoc or in an institutionalized manner, it seems important to impose and explain limits of government solidarity post as well as pre disaster. Clearly, compensation from a moral and welfare theoretic point of view is a necessity, and will be provided anyway given the political economy of government assistance. Yet, in the context of ever increasing losses, caused to a large extent due to people and assets locating in exposed floodplains, a fine balancing out of responsibilities coupled with social solidarity seems desirable. This would lead to better aligning ex post compensation with ex ante risk management in terms of reducing risks through taking preventive action, but also reducing financial exposure through insurance. It is evident that such government action would lead to increased allocative efficiency, yet have some sort of adverse distributional effect, as exposed households and business would need to take stronger action on their own.

Finally, as to the intergovernmental sharing of disaster expenditure in the EU, it seems rather straighforward to suggest to partially or completely revamp the EUSF from a purely ex post solidarity fund providing compensation support for larger scale events to a riskbased fund. Suggestions put forward by Hochrainer, Linnerooth-Bayer and Mechler in this issue comprise to remodel it as a government mutual insurance vehicle, to have it capitalize national public-private insurance programs or provide support for government, sovereign insurance solutions sought in the international markets. Such measures would favour allocation efficiency due to refocussing from impacts to risk, which would help better allocate resources to risk hotspots given today's unequal distribution of climate change impacts across regions and social groups with countries in the Mediterranean and Eastern and Southern Europe particularly exposed today and expected more so in the future due to changing precipitation extremes (EEA 2007; Kundzewicz et al. this issue). Finally, a better balanced fund would help to stabilize governments' positions affected by disaster stresses interacting with other stresses, and thus stabilize the economy overall.

\section{Conclusions}

According to Tabellini (2002), "the next steps for European integration concern the provision of public goods: defence, security, foreign policy, border control, are all public goods." Currently, however the EU spends mostly on redistribution in terms of regional development policies, and merely $15 \%$ of the total budget is spent on Union-wide public goods (Blankart and Kirchner 2004). Bracing the EU against the risks imposed by climate change constitutes 
one example of a public good. Given a limited budget, the EU has to make decisions on which adaptation measures - which may differ by type and host region - to carry out or to support, since not all possible options can likely be funded. From a normative welfare economics point of view, the choice should be guided by the pursuit of allocative efficiency, in line with goals of distribution and stabilization.

The increasing losses caused by extreme climate events challenge the role of the public sector in financially managing today's and future disaster events. Market forces are unlikely to generate adequate adaptation to climate risk due to uncertainty and imperfect information, missing and misaligned markets and financial constraints. This calls for government intervention, which we analyze according to its allocation, distribution, and stabilization functions. Regarding flood and drought risks, the approaches to insuring and compensating losses vary substantially across member states. The role of private insurance and government ex ante premiums or taxes is limited today in many EU countries. As a consequence, the extensive floods in central Europe at the beginning of the 21 st century resulted in the creation of the EU Solidarity Fund.

The current EU extreme event interventions are clearly not sufficient to cope with future extreme events projected to increase in size and intensity as a result of climate change. The three areas of public sector interventions, discussed, supporting national insurance systems, providing compensation to the affected post event as well as intergovernmental loss sharing through the EU solidarity fund, are examples where EU and member state policies may need to be further fine-tuned to better address today's and future challenges imposed by disaster risks. Clearly, public policy adaptation interventions imply trade-offs between allocative efficiency, distributional and stabilization aspects. As mentioned, the availability of public compensation schemes adversely affects incentives to buy private insurance. On the other hand, private market insurance might not be affordable for certain societal groups, and consequently, a government no-bail out policy would tend to threaten a desired distribution. There seems no optimal mix and solution in the mechanisms discussed, and as a general suggestion, country-specific circumstances need to be acknowledged and communicated clearly when suggestions for revisions of policies are heeded.

Finally, demonstrating market weakness or failure in the provision of public goods is not equivalent to establishing superiority of state interventions. Institutional arrangements where the state has a monopoly on the legitimate use of force are often connected with substantial state weaknesses as a provider of public goods. Bearing public sector implementation constraints in mind, certain forms of alternative associations and networks such as neighbourhood associations, communal organizations, international regimes, and public-private partnerships are often successfully used to solve aspects of collective action problems (Ostrom and Walker 2000). As one example, it seems that disaster adaptation measures often need to be carried out in terms of public-private partnerships in the form of better identifying, sharing and communicating risks between households, the insurance industry and national governments leading to better implementation, as well as more efficient, equitable and acceptable solutions in dealing with natural disaster events.

Open Access This article is distributed under the terms of the Creative Commons Attribution Noncommercial License which permits any noncommercial use, distribution, and reproduction in any medium, provided the original author(s) and source are credited. 


\section{References}

Aakre S, Rübbelke DTG (2010) Objectives of public economic policy and the adaptation to climate change. J Environ Plan Manag (forthcoming)

Agrawala S, Crick F, Fankhauser S, Hanrahan D, Jetté-Nantel S, Pope G, Skees J, Stephens C, Tepes A, Yasmine S (2008) Economic aspects of adaptation to climate change. OECD, Paris

Berkhout F (2005) Rationales for adaptation in EU climate policy. Clim Pol 5(3):377-391

Blankart CB, Kirchner C (2004) The deadlock of the EU budget: an economic analysis of ways in and ways out. In: Blankart CB, Mueller DC (eds) A constitution for the European Union. MIT, Cambridge, pp 109-138

Botzen WJW, van den Bergh JCJM (2008) Insurance against climate change and flooding in the Netherlands: present, future, and comparison with other countries. Risk Anal 28:413-426

Bouwer LM, Huitema D, Aerts JCJH (2007) Adaptive flood management: the role of insurance and compensation in Europe. Paper presented at the Conference on the Human Dimensions of Global Environmental Change, 24-26 May, Amsterdam

Comité Européen des Assurances (CEA) (2009) Tackling climate change The vital contribution of insurers. CEA, Brussels

Council Regulation (2002) (EC) No 2012/2002 of 11 Nov 2002 Establishing the European Union Solidarity Fund. Retrieved April 1, 2007 (http://europa.eu.int/eur-lex/pri/en/oj/dat/2002/1_311/1_31120021114en 00030008.pdf)

Crichton D (2002) UK and global insurance responses to flood hazard. Water Int 27:119-131

Crichton D (2008) Role of insurance in reducing flood risk. Geneva Pap Risk Insur 33:117-132

Culbertson JM (1974) Stabilization Policy in an Evolutionary Economics. In: Smith WL, Culbertson JM (eds) Public finance and stabilization policy. Essays in honor of Richard A. Musgrave. North-Holland Publishing Company, Amsterdam, pp 237-268

Devarajan S, Hammer JS (1997) New directions in public expenditure analysis. World Bank, Policy Research Department, Washington

Dlugolecki AF (2008) Climate change and the insurance sector. Geneva Pap Risk Insur 33:71-90

EC (2006) Agricultural Insurance Schemes, European Commission DG Agriculture and DG Joint Research Centre Final Report

EC (2007a) Adapting to climate change in Europe - options for EU action. Green Paper, Brussels: The Commission of the European Communities

European Commission EC (2007b) Addressing the challenge of water scarcity and droughts in the European Union. Communication from the Commission to the European Parliament and the Council, $\operatorname{COM}(2007)$ 414 final, July 2007

EC (2009) Adapting to climate change: towards a European framework for action. White Paper, Brussels: The Commission of the European Communities

EEA (2004) Impacts of Europe's changing climate. An indicator-based assessment. European Environment Agency Report 2/2004. Copenhagen

EEA (2007) Europe's environment. The fourth assessment. European Environment Agency, Copenhagen

Emanuel K (2005) Increasing destructiveness of tropical cyclones over the past 30 years. Nature 436:686688

EUFR (2002) EU Financial Report. Luxembourg: Office for Official Publications of the European Communities. Retrieved April 1, 2007 (http://europa.eu.int/comm/budget/lilbrary/publications/fin_reports/ fin_report_02_en.pdf)

EUFR (2004) EU Financial Report. Luxembourg: Office for Official Publications of the European Communities. Retrieved April 1, 2007 (http://europa.eu.int/comm/budget/lilbrary/publications/fin_reports/ fin_report_04_en.pdf)

Hallegatte S $(\overline{2009})$ Strategies to adapt to an uncertain climate change Global Environmental Change Part. doi:10.1016/j.gloenvcha.2008.12.003

IDB (2000) Facing the challenge of natural disasters in Latin America and the Caribbean. An IDB action plan. Inter-American Development Bank, Washington

International Strategy for Disaster Reduction (ISDR) (2005) National platforms for disaster risk reduction. National reports. Retrieved February 20, 2009 (http://www.unisdr.org/eng/country-inform/introduction.htm)

Klein RJT, Tol RSJ (1997) Adaptation to climate change: options and technologies, an overview paper. Technical Paper FCCC/TP/1997/3, United Nations Framework Convention on Climate Change Secretariat, Bonn, Germany. Retrieved January 5, 2009 (http://www.unfccc.int/resource/docs/tp/tp3.pdf)

Knight FH (1921) Risk, uncertainty, and profit. Hart, Schaffner \& Marx; Houghton Mifflin Company, Boston

Kunreuther H (1998) Introduction. In: Kunreuther H, Roth S (eds) Paying the price: the status and role of insurance against natural disasters in the United States. Joseph Henry Press, Washington 
Linnerooth-Bayer J, Mechler R (2007) Insurance against losses from natural disasters in developing countries. Background paper for United Nations World Economic and Social Survey (WESS)

McEvoy D, Matczak P, Banaszak I (this issue) Framing adaptation to climate-related extreme events

Mechler R (2004) Natural disaster risk management and financing disaster losses in developing countries. Verlag für Versicherungswirtschaft, Karlsruhe

Mechler R, Hochrainer S, Aaheim A, Kundzewicz Z, Lugeri N, Moriondo M, Salen H, Bindi M, Banaszak I, Chorynski A, Genovese E, Kalirai H, Linnerooth-Bayer J, Lavalle C, McEvoy D, Matczak P, Radziejewski M, Rübbelke D, Schelhaas M-J, Szwed M, Wreford A (2010) A risk management approach for assessing adaptation to changing flood and drought risks in Europe. In: Hulme M, Neufeldt H (eds) Making climate change work for us: European perspectives on adaptation and mitigation strategies. Cambridge University Press, Cambridge, pp 200-229

Mendelsohn R (2000) Efficient adaptation to climate change. Clim Change 45:583-600

Munich Reinsurance Company (2002) Topics: natural disasters 2001. Annual Review of Natural Disasters Munich, Munich Reinsurance Group

Musgrave RA (1959) The theory of public finance. McGraw Hill, New York

Organisation for Economic Co-operation and Development (OECD) (2005) catastrophic risks and insurance, policy issues in Insurance No. 8, Paris: Organisation for Economic Co-operation and Development

Ostrom E, Walker J (2000) Neither markets nor state: linking transformation processes in collective action arenas. In: McGinnis MD (ed) Polycentric games and institutions. Readings from the workshop in political theory and policy analysis. The University of Michigan Press, Ann Arbor

Paklina N (2003) Flood insurance. Organisation for Economic Co-operation and Development, Paris

Priest GL (1996) The government, the market, and the problem of catastrophic loss. J Risk Uncertain 12:219-237

Schönwiese C-D, Grieser J, Troemel S (2003) Secular change of extreme monthly precipitation in Europe. Theor Appl Climatol 75(3-4):245-250

Skees JR (2001) The bad harvest: more crop insurance reform: a good idea gone awry. The CATO Review of Business and Government 24:16-21

Smit B, Burton I, Klein RJT, Street R (1999) The science of adaptation: a framework for assessment. Mitig Adapt Strateg Glob Change 4:199-213

Smit B, Burton I, Klein RJT, Wandel J (2000) An anatomy of adaptation to climate change and vulnerability. Clim Change 45:223-251

Solomon S, Qin D, Manning M, Chen Z, Marquis M, Averyt KB, Tignore M, Miller HL (eds) (2007) Climate change 2007: the physical science Basis. Contribution of Working Group I to the Fourth Assessment Report of the Intergovernmental Panel on Climate Change. Cambridge University Press, Cambridge

Stern N (2007) The economics of climate change - the stern review. Cambridge University Press, Cambridge

Swiss Reinsurance Company (Swiss Re) (1998) Floods: an insurable risk? Swiss Reinsurance Company, Zurich

Tabellini G (2002) The EU needs new financial arrangements. CEPS Analysis Retrieved on December 20, 2008 (http://www.euractiv.com/en/future-eu/eu-needs-new-financial-arrangements/article-110050?)

Treby EJ, Clark MJ, Priest SJ (2006) Confronting flood risk: implications for insurance and risk transfer. J Environ Manage 81:351-359

Van den Bergh R, Faure M (2006) Compulsory insurance of loss to property caused by natural disasters: competition or solidarity? World Compet 29:25-54

Whyley C, McCormick J, Kempson E (1998) Paying for peace of mind: access to home contents insurance for low-income households. Policies Studies Institute, London 